\title{
A novel transition to practice curriculum for CCFP(EM) programs
}

\author{
Avik Nath $^{1} \cdot$ Warren J. Cheung ${ }^{1,2} \cdot$ Jennifer Leppard ${ }^{1} \cdot$ Jeffrey J. Perry ${ }^{1,2,3}$ \\ Received: 4 August 2020 / Accepted: 22 October 2020 / Published online: 12 March 2021 \\ (c) Canadian Association of Emergency Physicians (CAEP)/ Association Canadienne de Médecine d'Urgence (ACMU) 2021
}

\begin{abstract}
We implemented a novel transition-to-practice curriculum incorporating four new processes to prepare CCFP(EM) residents for independent practice. These elements were: 1) explicit sequencing of competency progression; 2) establishment of coaching teams; 3) establishment of independent shifts; and 4) implementation of a transition-to-practice seminar series. Exit surveys of residents rated the new curriculum highly with $15 / 17(88.2 \%)$ residents reporting they felt prepared for independent practice. All residents rated competency progression, coaching teams, independent shifts and transition-to-practice series favourably. This framework can be used by other 1-year enhanced skills or other fellowship programs to prepare their residents for independent practice.
\end{abstract}

Keywords Transition to practice $\cdot$ CCFP(EM) $\cdot$ Enhanced skills $\cdot$ Emergency medicine

\section{Résumé}

Nous avons mis en place un nouveau programme de transition vers la pratique qui intègre quatre nouveaux processus pour préparer les résidents du CCFP(EM) à la pratique indépendante. Ces éléments étaient : 1) l'enchaînement explicite de la progression des compétences ; 2) la mise en place d'équipes d'encadrement ;3) la mise en place mise en place de quarts de travail indépendants; et 4) la mise en œuvre d'une série de séminaires de transition vers la pratique. Les sondages de sortie des résidents ont donné une note élevée au nouveau programme avec 15/17 (88,2\%) les résidents déclarant qu'ils se sentaient prêts à pratiquer de façon indépendante. Tous les résidents ont accordé une note favorable à la progression des compétences, aux équipes d'encadrement, aux quarts de travail indépendants et à la transition vers la série de pratiques. Ce cadre peut être utilisé par d'autres programmes de perfectionnement des compétences d'un an ou d'autres programmes de bourses pour préparer leurs résidents à la pratique indépendante.

\section{Background}

The CCFP(EM) residency training program is 1-year enhanced skills training in emergency medicine (EM) following a 2-year family practice residency. It is designed to equip graduating residents with skills to practice EM. This 1 -year program requires rapid acquisition of new skills and

Avik Nath

anath@toh.ca

1 Department of Emergency Medicine, University of Ottawa, Civic Campus, 1053 Carling Ave, Ottawa, ON K1Y 4E9, Canada

2 Clinical Epidemiology Program, Ottawa Hospital Research Institute, Ottawa, ON, Canada

3 School of Epidemiology and Public Health, University of Ottawa, Ottawa, ON, Canada practice readiness. In Canada, competency-based residency programs started with the introduction of CanMEDS-Family Medicine in 2009 [1], Triple C Competency-based Curriculum in 2011 [2], and Competence by Design in all Royal College training programs starting in 2017, with Emergency Medicine implementing in 2018 [3]. The importance of a resident's ability to transition to practice has been highlighted in each of these frameworks. A recent survey demonstrated that only $24 \%$ of CCFP(EM) programs in Canada have a "transition-to-practice" curriculum [4]. In the 6-month Transition to Practice stage of Competence by Design, the senior resident hones their competencies as they prepare for independent practice [3]. However, rather than a discrete stage, such as in Competence by Design, the $\mathrm{CCFP}(\mathrm{EM})$ training program necessitates that transition to practice occurs early and continuously during the resident's 1 -year training. 


\section{Purpose or rationale}

We aimed to design and implement a transition-to-practice curriculum to prepare residents for independent practice.

\section{Description of the innovation}

The four new components were:

\section{Explicit sequencing of competence progression} (Fig. 1):

We developed a "Progression of Competence" shift card based on the framework suggested by Frank et al. [5]. Using a modified Delphi method [6], a group of emergency physicians (EPs) sought to tailor these competencies for CCFP(EM) trainees based on CanMEDS-FM domain [1]. A group of $6 \mathrm{CCFP}(\mathrm{EM})$ and 1 FRCPC EP including previous program directors, and educational experts at the University of Ottawa Department of Emergency Medicine, convened 3 times over 6 months. An initial list of competencies based on stages of training was developed. Stages were broken down into early (1st and 2nd EM rotations), middle (3rd and 4th EM rotations) or late (5th and 6th EM rotations). This initial list was then sent to all staff EP's at The Ottawa Hospital (TOH) for comments. After incorporating feedback, the list of stage-based competencies of training was finalized (Fig. 1). Laminated progression of competence cards were distributed to new residents at orientation. Staff EP's were oriented to and provided with cards at the start of the year. Residents were encouraged to discuss specific objectives at the beginning of their shift with their supervising physician using the card as a reference. This allowed residents and EP's to establish a shared mental model of expectations of trainees at each stage.
Fig. 1 Progression of competence shift card

\begin{tabular}{|c|c|c|c|}
\hline & $\begin{array}{c}\text { Early } \\
\left(1^{\text {st }} / 2^{\text {nd }} \text { month }\right)\end{array}$ & $\begin{array}{c}\text { Middle } \\
\left(3^{\text {rd }} / 4^{\text {th }} \text { month }\right)\end{array}$ & $\begin{array}{c}\text { Late } \\
\left(5^{\text {th }} / 6^{\text {th }} \text { month }\right)\end{array}$ \\
\hline Medical Expert & $\begin{array}{l}\text { Complete } \\
\text { differential } \\
\text { diagnosis, } \\
\text { independent } \\
\text { workup, and } \\
\text { management plan } \\
\text { of patients }\end{array}$ & $\begin{array}{l}\text { Efficiently manage } \\
\text { multiple patients }\end{array}$ & $\begin{array}{l}\text { Recognize uncommon } \\
\text { and atypical } \\
\text { presentations }\end{array}$ \\
\hline \multirow[t]{3}{*}{ Communicator } & Break bad news & Conflict resolution & \\
\hline & $\begin{array}{l}\text { Present own cases } \\
\text { at handover }\end{array}$ & $\begin{array}{l}\text { Deliver handover of an } \\
\text { area of the emergency } \\
\text { department }\end{array}$ & $\frac{\text { Accept and deliver }}{\text { handover efficiently }}$ \\
\hline & $\begin{array}{l}\text { Complete charting } \\
\text { including } \\
\text { reassessments }\end{array}$ & & \\
\hline Collaborator & $\begin{array}{l}\text { Enable appropriate } \\
\text { involvement of } \\
\text { allied health } \\
\text { professionals }\end{array}$ & $\begin{array}{l}\text { Accept consults with } \\
\text { supervision }\end{array}$ & \\
\hline $\begin{array}{l}\text { Health } \\
\text { Advocate }\end{array}$ & \multicolumn{3}{|c|}{ Address socioeconomic issues and ethical dilemmas } \\
\hline \multirow[t]{2}{*}{ Manager } & $\begin{array}{l}\text { Optimize flow for } \\
\text { individual patients }\end{array}$ & $\begin{array}{l}\text { Optimize flow in an area } \\
\text { of the emergency } \\
\text { department and answer } \\
\text { patch ambulance phone }\end{array}$ & $\begin{array}{l}\text { Optimize flow in the } \\
\text { entire emergency } \\
\text { department }\end{array}$ \\
\hline & Billing & Quality Assurance (QA) & $\begin{array}{l}\text { Supervise and teach } \\
\text { junior learners }\end{array}$ \\
\hline Scholar & $\begin{array}{l}\text { Utilize resources } \\
\text { efficiently to } \\
\text { answer clinical } \\
\text { questions on shift }\end{array}$ & & \\
\hline Professional & \multicolumn{3}{|c|}{$\begin{array}{l}\text { Demonstrate all aspects of professional behavior including reporting } \\
\text { obligations }\end{array}$} \\
\hline
\end{tabular}


Table 1 Exit survey results for CCFP-EM residents at time of completion of residency from 2018-2020 $(N=17)$

Survey questions (scale)

(Number of positive responses $* * /$ number of residents in program)

Independent shifts:

2019-2020: 6/6

I found the independent practice shifts useful 2018-2019: 5/5

(yes/no)

2017-2018: 6/6*

Clinical coaching teams:

2019-2020: 6/6

Do you like the idea of clinical teaching teams?

2018-2019: 5/5

(yes/no)

2017-2018: 6/6

Increasing independence:

I found there was progression of my independence and I was given increasing responsibility as the year progressed

2019-2020: 6/6

2018-2019: 5/5

(yes/no)

2017-2018: 6/6*

Transition to practice academic seminars:

2019-2020: 6/6

I felt there were enough academic sessions (e.g. billing/ medico-legal issues) given to help me transition to a staff emergency physician

(yes/no)

2017-2018: 4/6*

Overall:

2019-2020: 6/6

I feel ready to go practice in any ED setting in Canada

2018-2019: 5/5

(yes/no)

2017-2018: 4/6*

* One resident did not respond to this question and was not included in final number of respondents

** Positive response was either "yes" or "excellent/ very good/ good"

\section{Clinical coaching teams}

We utilized 'clinical coaching teams' that were composed of 3 EP's assigned to each resident. Residents were scheduled to work 3-6 shifts with each coach when on a core EM rotation with the intent of establishing an educational alliance [7]. This allows for comfort with practice style for both physician and resident, continuity of teaching and learning, continuous assessment, and mentoring throughout the year. It builds confidence and trust in the resident and it was postulated that this would facilitate a smoother transition into independent practice.

\section{Independent shifts}

In a resident's last stage of their training, they were assigned to work independently in the low acuity care area to build their autonomy and work on patient flow. A supervising physician is assigned to each resident and meets them near the end of their shift to review all cases and discuss nuances of patient management, billing, charting, medico-legal aspects, flow and independent decision-making.

\section{Transition to practice seminars}

A series of seminars were designed to incorporate previously identified transition-to-practice curricula [8] including: billing; personal finance management; wellness; medico-legal pitfalls and going to court; flow and medical charting; contract negotiation; as well as educational considerations including on-shift teaching and managing multiple learners. Seminars varied in length from 1 to $3 \mathrm{~h}$ and were given by staff EP's from $\mathrm{TOH}$ and external content experts.

\section{Results}

The utility of these curricular components as perceived by residents was assessed through exit surveys conducted over the last 3 years since implementation (Table 1). 100\% of residents surveyed found independent shifts useful and liked the idea of clinical coaching teams. All residents found there was progression of their independence and that they were given increasing responsibility as the year progressed. Finally, 15/17 (88.2\%) residents reported they felt ready for independent practice at the end of training.

\section{Discussion}

We developed an evidence-based, novel transition-to-practice curriculum. The four components are not resourceintensive and can be implemented by other programs. Having a user-friendly, low-cost, aesthetically pleasing reference 
resource has been shown to have a positive impact on transition to Competence by Design [9]. Using the Progression of Competence shift cards ensures both learner and supervisor are clear on goals and expectations of abilities and skills at each stage of training. Coaching is a teaching modality in medical education that has been shown to improve clinical skills [10]. Focusing on development through coaching teams early on allows for continuous assessment and trust for both resident and supervisor, enabling a smoother transition to independence. In the Triple $\mathrm{C}$ curriculum, this exemplifies 'Continuity of Education' [2], specifically, continuity of supervision and assessment. Residents found independent practice shifts useful to build confidence and autonomy while balancing appropriate supervision and teaching through a strong educational alliance established with their clinical coaches [7]. Finally, transition-to-practice seminars allows for targeted education for must-know content. Collectively, these curricular components allow residents to prepare for independent practice in a safe and familiar setting.

As part of the FRCP-EM program's Competence by Design implementation, variations of clinical coaching teams, independent shifts and transition-to-practice seminars are concurrently used. While this study was limited to CCFP-EM residents, it is likely the positive impact of these components will also be applicable to the FRCP cohort.

Further collaboration and sharing of innovations from other programs may further inform curricular design. Furthermore, assessing how these curricula assisted residents 1-2 years after independent practice would be informative. Development of a robust transition-to-practice model would allow this curriculum to be applied nationally not only by CCFP(EM) programs, but also other Family Medicine enhanced skills programs and other RCPSC 1-year fellowships.

\section{Summary}

We described a novel transition-to-practice curriculum for the CCFP(EM) 1-year training program. Residents responded positively to this curriculum that prepared them to transition to independent practice. This framework may be used by other programs to improve residents' readiness for independent practice.
Author contributions All authors contributed to the writing of the manuscript.

Funding None.

\section{Compliance with ethical standards}

Conflict of interest None.

\section{References}

1. Shaw E, Oandasan I, Fowler N, editors. CanMEDS-FM 2017: a competency framework for family physicians across the continuum. Mississauga: The College of Family Physicians of Canada; 2017.

2. Tannenbaum D, Kerr J, Konkin J, Organek A, Parsons E, Saucier D, Shaw L, Walsh A. Triple C competency-based curriculum. Report of the working group on postgraduate curriculum reviewPart 1. Mississauga, ON: College of Family Physicians of Canada; 2011.

3. The Royal College of Physicians and Surgeons of Canada. Competence by Design (CBD) and exams; 2018. Available at: https ://www.royalcollege.ca/rcsite/cbd/assessment/cbd-exams-e)(cbdcompetence-continuum-diagram-legal-e.pdf (Accessed June 20, 2020).

4. Nath A, Yadav K, Perry J. Describing CCFP(EM) programs in Canada: A national survey of program directors. CJEM. 2019;21(2):274-82. https://doi.org/10.1017/cem.2018.374.

5. Frank JR, Danoff D. TheCanMEDS initiative: implementing an outcomes-based framework of physician competencies. Med Teach. 2007;29(7):642-7. https://doi.org/10.1080/0142159070 1746983.

6. Dillman DA. Mail and Internet surveys: the tailored design method. 2nd ed. Hoboken: Wiley; 2007.

7. Telio S, Regehr G, Ajjawi R. Feedback and the educational alliance: examining credibility judgements and their consequences. Med Educ. 2016;50(9):933-42.

8. Caretta-Weyer H. Transition to practice: a novel life skills curriculum for emergency medicine residents. West J Emerg Med. 2019;20(1):100-4. https://doi.org/10.5811/westj em.2018.10.39868.

9. Stoneham E, Witt L, Paterson Q, Martin L, Thoma B. The development of entrustable professional activities reference cards to support the implementation of Competence by Design in emergency medicine. CJEM. 2019;21(6):803-6. https://doi. org/10.1017/cem.2019.395.

10. Lovell B. What do we know about coaching in medical education? A literature review. Med Educ. 2018;52:376-90. https://doi. org/10.1111/medu.13482. 